\title{
IMPROVING ORAL COMMUNICATION THROUGH DIRECT METHOD IN RURAL
}

\section{SCHOOLS OF TELANGANA}

\section{NALLALA HIMA VARSHINI ${ }^{1} \&$ RAJA AMBETHKAR ${ }^{2}$}

${ }^{1}$ Research Scholar, Koneru Lakshmaiah Education Foundation, Waddeswaram Deemed University, Guntur,

\author{
Andhra Pradesh, India
}

${ }^{2}$ Associate Professor Koneru Lakshmaiah Education Foundation, Waddeswaram, Deemed University, Guntur,

Andhra Pradeshm, India

\begin{abstract}
Proficiency in English language plays an important role in various fields ranging from politics and journalism to everyday communication. Good communication skills will go a long way in developing good interpersonal relationships at the workplace. Subsequent to the advent of globalization and reduction of the world to a global village, the need for proficiency in English language speaking has become much starker. The mobility of people across countries has multiplied manifold and the boundaries between nations have collapsed. Consequently, the need for an international language, which would facilitate social intercourse among people belonging to various languages, arose. English fulfilled that need and emerged as the lingua franca. This paper focuses on one of the best and the most natural way of imparting oral language teaching to the students i.e. The direct method.

KEYWORDS: Globalization, Lingua Franca, Best Method of Teaching \& The Direct Method
\end{abstract}

\section{INTRODUCTION}

The world started becoming economically integrated and interdependent from the late twentieth century. People started moving freely from one country to the other, in search of trade and investment opportunities. Meanwhile, population exploded in the third world countries. Unable to compete for the scarce resources, these developing countries offered, people started migrating to the industrialized, well developed and the English speaking countries of the West and Europe. This migration necessitated command over English language communication skills. Language teachers in the third world countries scrambled to find out the effective ways of imparting these much sought-after skills to their wards. Many strategies were developed, subsequently, to teach oral skills in English language to the non native students. This paper studies the efficacy of one such strategy: the direct method of teaching the students directly in the target language, i.e. English without resorting to translation is called as direct method. This method of teaching rests on the belief that communication skills can be better imparted through speaking in the target language rather than bothering about the grammatical rules. It leaves no stone unturned in tuning the student's mindsets to think and act in the target language, instead of their mother tongues. To put in a nutshell, the direct method is the most natural way of oral language teaching to the non native students.

\section{DATA COLLECTION}

A group of 30 students studying IX $^{\text {th }}$ in Govt high school, Rechini, Telangana was selected for the study. 
They were 20 male and 10 female students of the same age group. The students were taught the target language in the direct method for an academic year i.e., around 10 months.

Data for the qualitative study was collected through interviews and classroom observations. Wide-open interview (See Appendix B) and Semi-Structured interview (See Appendix C) were conducted at the end of research period each student was personally evaluated and feedback was also received from them about how confident they felt while speaking and the difference the 10 months of teaching made to their confidence levels.

\section{Guidelines Followed for the Study}

- Translation was avoided completely. Demonstration was used instead to explain the meaning of the sentences to the students.

- Explanation was avoided right from the word go. The teacher took great pains to act the sentences out.

- Giving lectures was consciously avoided. The teacher interacted with the students through regular Q\&A sessions.

- No stone was left unturned by the teacher to provide a congenial atmosphere for the impoverished rural students to shed their inhibitions and speak out in an alien language. Mistakes were not scoffed at but corrected patiently.

- A proper lesson plan was made and it was executed meticulously without using a textbook.

- The pace of the speaking was kept in tune with the levels of the students' understanding

- Particular care was taken on the pitch of the voice. It was never allowed to be too low or too high.

- Questions were put to the students and efforts were made to elicit responses from them

- The students were encouraged to read sections of a passage, or a lesson or a play.

- General topics like the village problems were given to the students and they were asked to engage in a dialogue.

- Dictations were conducted on a regular basis.

\section{DATA ANALYSIS}

The pre- and post-course oral proficiency test elicited valuable speech data from the thirty students and provided information about how their communicative competence improves during the period of the study. For Data analysis, I described participants and tried to present their attitudes towards direct method of language learning in tables and used Microsoft Excel 2007.

\section{RESULTS AND DISCUSSIONS}

20 male and 10 female students are responded in the affirmative when asked whether they felt confident while speaking in English language. Six students opined that they were better than they were before the start of the study. A majority of the students, that is 12 out of the 30 , accounting for $40 \%$, felt that their ease of forming the sentences had improved. Finding out the right words to express their feelings was the major concern for 9 out of the 30 students, equal to $30 \%$. Remaining student's i.e 3 out of the 30 or $10 \%$ felt that the direct method of oral language teaching was not effective for learning the communication skills in a natural way. All the students were in unison when asked whether the lack of English speaking atmosphere at home and rest of the school hours is holding them back. 


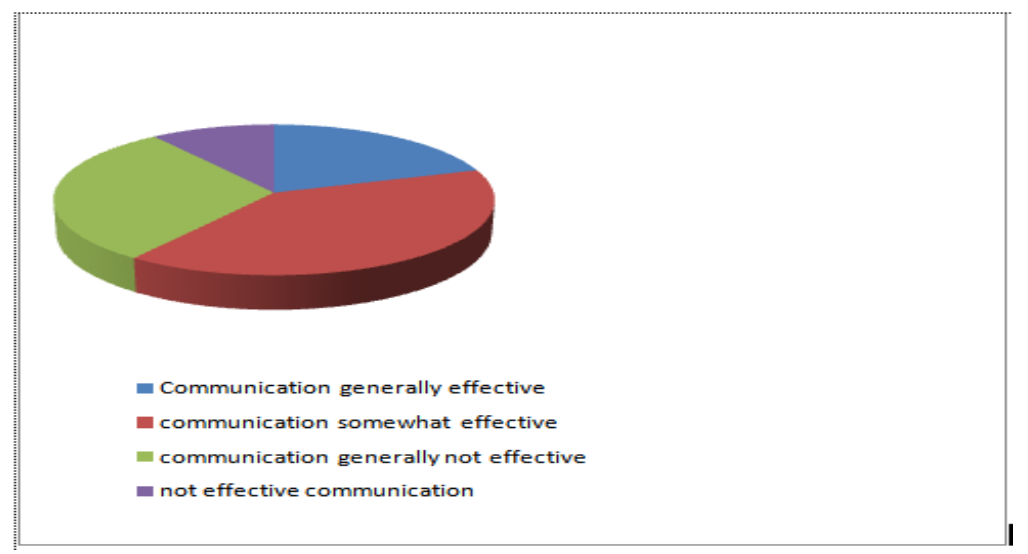

Figure 1

Data display of the Thirty students Communicative Effectiveness in English

\section{Constraints Observed During the Course of the Study}

- The study required a lot of audio-visual aids, which were found to be in short supply at this hinterland school. Many schools this author has visited, in the course of the study, were found to be the same. This was found to be a major stumbling block to the direct method of teaching.

- The teachers were lacking in both competence and motivation, in teaching the language in direct method.

- Demonstration of each and every word and concept was found to be a herculean task in the Indian classroom setting. This researcher has realized that this time consuming process of demonstration could not be carried out for entire course prescribed for the students, owing to paucity of time.

\section{CONCLUSIONS}

The direct method of oral language teaching is one of the most effective strategies to impart target language to the students, as this method involves the use of audio visual aids. But, given the various constraints like the non availability of basic infrastructure in the schools, a severe shortage of time in implementing the strategy and a lack of committed and competent workforce to put the method into practice, this method is found to be falling short of the expected results. The way forward is an intelligent mix of direct method and other complementary strategies to realize the objectives.

\section{REFERENCES}

1. Tickoo, M. L. (2004). ELT in India. New Delhi: Orient Longman.

2. Jack C. Richards and Theodore S. Rodgers, (2010). Approaches and methods in Language teaching. Cambridge University press.

3. Claudius, Gowtham , Sowmya, Hybrid Implementation of Cooperative Learning is One of the Solutions for the Current Problems of EFL/ESL Teaching in Indian Schools, International Journal of English and Literature (IJEL), Volume 6, Issue 1, January - February 2016, pp. 37-46

4. Dr. Shaik mowla, (2009). Methods of teaching English. Neelkamal Publications Pvt.Ltd.

5. Developing_ Communicative_ Through_ Drama_ Oriented activities_ in_ an_ EFL_ Classroom. www.paalijapan.org $>$ pdf $>$ pdf003. 


\section{APPENDIX A}

Examples of Open ended Scenarios

- $\quad$ Role play

At a Departmental store

Role A: You must be a Customer to buy something from a Departmental store. Prepare yourself how to talk to a sales

clerk.

Role B: You are a sales clerk and prepare yourself to deal with some customer who is approaching you.

- Village Problems

- Selecting some students and ask them to mention their problems in their villages like

- $\quad$ transport and roads

- water

- $\quad$ Electricity

\section{APPENDIX B}

Wide open interview

- Personal Data

- Asking their age their areas of interests, Hobbies, Their experiences of learning English

○ How's your own feeling about yourself as a person and yourself as a learner?

- Why do you volunteer to participate in this study? In what ways do you believe this study might be of help?

\section{APPENDIX C}

Semi - Structured Interview

- Did you feel confident while speaking?

- Were you at ease at forming sentences?

- What was the biggest problem encountered by you while speaking?

- Did you feel direct method of teaching was better over other methods?

- What was the toughest aspect in DT method?

- What was the biggest difference, in the English classrooms after the introduction of DT method? 